by N. N. Chombong and C. E. Suh

\title{
2883 Ma commencement of BIF deposition at the northern edge of Congo craton, southern Cameroon: New zircon SHRIMP data constraint from metavolcanics
}

Economic Geology Unit, Department of Geology, University of Buea, P.O. Box 63, Buea, South West Region, Cameroon. E-mail: nchombong@yahoo.com

New SHRIMP data for zircons separated from a metadacite interbedded with banded iron formation (BIF) in the Mbalam region of southern Cameroon provide a 2883 $\pm 20 M a$ age for the commencement of BIF deposition in the Congo craton. Separated zircons from the associated metadacite are brown and euhedral to subheral in form with distinct oscillatory zoning typical of magmatic signatures. These zircons lack internal resorption features and serrated zone boundaries as should be expected of zircons inherited from the surrounding basement rocks or multiple magmatic plumbing events. However, zircons from a surface BIF sample collected $\sim 60 \mathrm{~km}$ west of the sequence from which the metavolcanics were sampled show a different age spectrum (Palaeoproterozoic, 1.0-2.0 Ga) suggesting a latter stage of BIF formation in the region which is not the focus of this work. Geochemical features of the metavolcanic samples analyzed identify the rocks to be rhyolitic, dacitic to andesitic in composition and possibly formed from a single magma by simple fractional crystallization. Trace element plots show negative $\mathrm{Nb}$, $\mathrm{Ta}$, Ti and Ho peaks that are characteristic of arc magmas. The study shows that initial BIF deposition in the Congo Craton was associated with early arc magmatism in the Archean. These ages correlate reasonably with early BIF deposition across the Atlantic in Brazil which was once linked to the Congo craton prior to the breakup of Gondwana.

\section{Introduction}

Banded Iron Formations (BIF) are chemical sediments thought to have been formed in an open ocean when the earth's oxygen was still very low (Bekker et al., 2004; Kaufman et al., 2007 and Konhauser et al., 2002, 2007b). Typically, BIF consists of alternating Si- and Ferich layers with an evaluated total Fe and Si content of $20-40 \mathrm{wt} \%$ and $43-56 \mathrm{wt} \%$, respectively (Klein, 2005). The deposition of BIF is linked to a contemporaneous process in which clastic sediments from the continent were being deposited in the ocean along with the upwelling of hydrothermal fluids at the Mid-Ocean-Ridge (MOR) (Bau and Möller, 1993; Clout and Simonson, 2005 and Beukes and Gutzmer, 2008). Lavas intercalated with BIF provide a direct tool for constraining the timing of BIF formation in a paleobasin. The determination of BIF depositional age is vital to date key events in the evolution of the biosphere. Precise age constraints on the iron formation across the world both advance our understanding of BIF genesis and enable current stratigraphic and tectonic models to be evaluated. This paper dates for the first time BIF deposition within the Ntem Complex at the Northern edge of the Congo Craton by SHRIMP U-Pb method using zircons separated from associated volcanic material (Fig. 1). In addition, zircons separated from a surface BIF sample in the region are also dated to determine if other BIF depositional events occurred after the Archean phase of BIF formation. These results provide new insights for the correlation of Gondwana fragments in Africa (Congo craton) with those of South America (São Francisco craton) and also allow a better comprehension of the relation between volcanism and BIF deposition in pre-Gondwana break-up setting.

\section{Overview of geology}

The Ntem Complex represents the extension of the northern edge of the Congo Craton in Cameroon. Mesoarchean to Neoarchean charnockitic rocks usually of TTG composition (Takam et al., 2009 and Shang et al., 2010) and greenstones associated with metasedimentary formations make up the basement rock suit of the Ntem Complex (Shang, 2001; Pouclet et al., 2007 and Shang et al., 2007). Rocks of the TTG suite are strongly mylonitized and retrogressed along the thrust boundary with the Pan-African Yaounde Group (Takam et al., 2009). Late high-K granites and dolerite dykes generally younger than the TTG and greenstone belts occur as intrusions clearly distinct from the older TTG (Shang et al., 2007, 2010) (See Fig. 2). These have been interpreted as a heat source for remelting TTG and charnockites to generate high-K granites thus suggesting the coeval nature of doleritic magmatism and high-K 


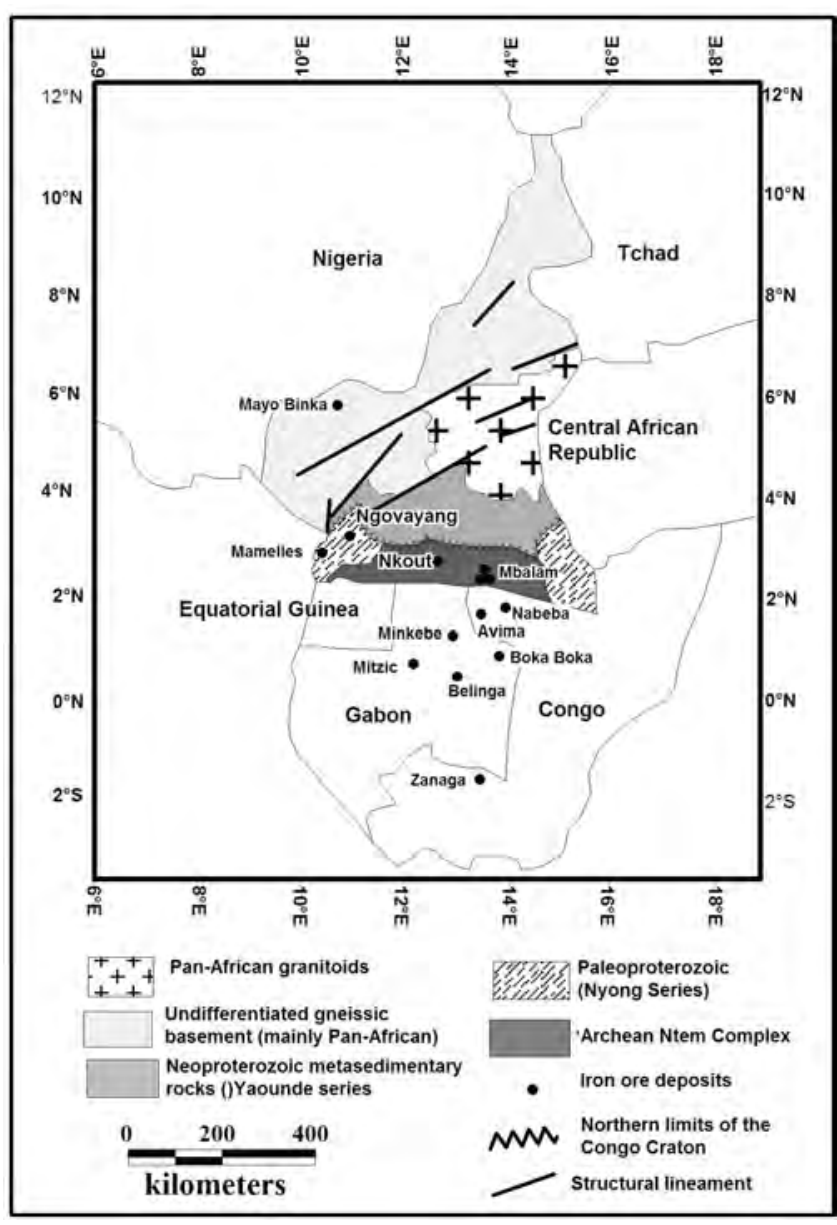

Figure 1. A Regional map showing iron ore deposits within the Congo Craton (Modified after Suh et al., 2008)
$\mathrm{N} 120 \mathrm{E}$ and N-S. This is evident from relict greenstone belts and the TTG series (Shang, 2001 and Shang et al., 2004a). Sinistral shear planes that trend $\mathrm{N}-\mathrm{S}$ to $\mathrm{N} 45 \mathrm{E}-\mathrm{N} 50 \mathrm{E}$ define $\mathrm{C}_{2}$ surfaces that are associated with partial melting of the TTG rocks (Tchameni et al., 2001 and Shang et al., 2004a). $\mathrm{D}_{3}$ and $\mathrm{D}_{4}$ define transcurrent tectonics that are steeply dipping and represented by $\mathrm{C}_{3}$ mylonitic and shear corridors observed near the contact zone with the Yaoundé nappe front (Shang et al., 2004a and Takam et al., 2009).

BIF of the Congo craton have received very little attention to date. Within the Ntem complex in southern Cameroon, reconnaissance BIF geochemistry, mineralogy and structure have been reported by Suh et al. $(2008,2009)$ and Nforba et al. (2010). The iron ore concentrates attain grades as high as $96 \mathrm{wt} \% \mathrm{Fe}$ although the protore has $20-45 \mathrm{wt} \% \mathrm{Fe}$. The enriched ore consists of hematite and martite with minor goethite. Two BIF facies are encountered in the area, namely the oxide and silicate facies. Banding in both facies is distinct and mesobands rarely exceed $1 \mathrm{~cm}$. The oxide facies BIF is composed of quartz as the main gangue mineral associated with various iron oxides, principally martite, goethite and magnetite. The iron oxide phases could be granular, massive or finely disseminated. The silicate facies (amphibolitic facies) is characterized by abundant brown goethite pseudomorphs after silicate minerals (amphiboles) (Ilouga et al. 2012, in press). The bands present similar textures as above, in addition to the alternating white to yellowish silica bands and light green to dark massive iron oxides bands. The common minerals that accompany the silicate in reflected light microscopy are martite, magnetite, goethite, and quartz

Recently, commendable exploration efforts by CamIron (a subsidiary of Sundance Resources, an Australian based company) and Afferro Mining on the Cameroon sector have led to the discovery of prospective major iron ore deposits within the paleobasin at Mbalam

granite genesis (Shang et al., 2007, 2010). The high-K granites include monzogranites and syenogranites that occur as leucocratic pods and tongues associated with mafic restite and small scale pegmatitic and aplitic veins and dykes. Biotites and amphiboles dominate the restites while microcline, albitic plagioclase and quartz makeup the primary mineral assemblages with myrmerkitic textures common at the contact between microcline and plagioclase (Shang et al., 2010). Iron ore associated with BIF (Ilouga, in press; Suh et al., 2008; Suh et al., 2009 and Nforba et al., 2010) and the ultramafic rocks with elevated $\mathrm{Ni}, \mathrm{Cr}$ and Co contents (Milesi et al., 2006) constitute the economic lithologies of the Ntem Complex.

Structural and petrological studies have identified two major Archean deformations at the northwestern edge of the Congo craton (Tchameni et al., 2000). D1 is non-rotational and defines hypersolidus textures and late joints linked to crystallization (Feybesse et al., 1998). D2 deforms the $S_{1}$ foliation into low amplitude folds (Feybesse et al., 1998) and is accompanied by the emplacement of plutons, diapirism and recrystallization. The $S_{2}$ foliation is vertical and oriented N80E to

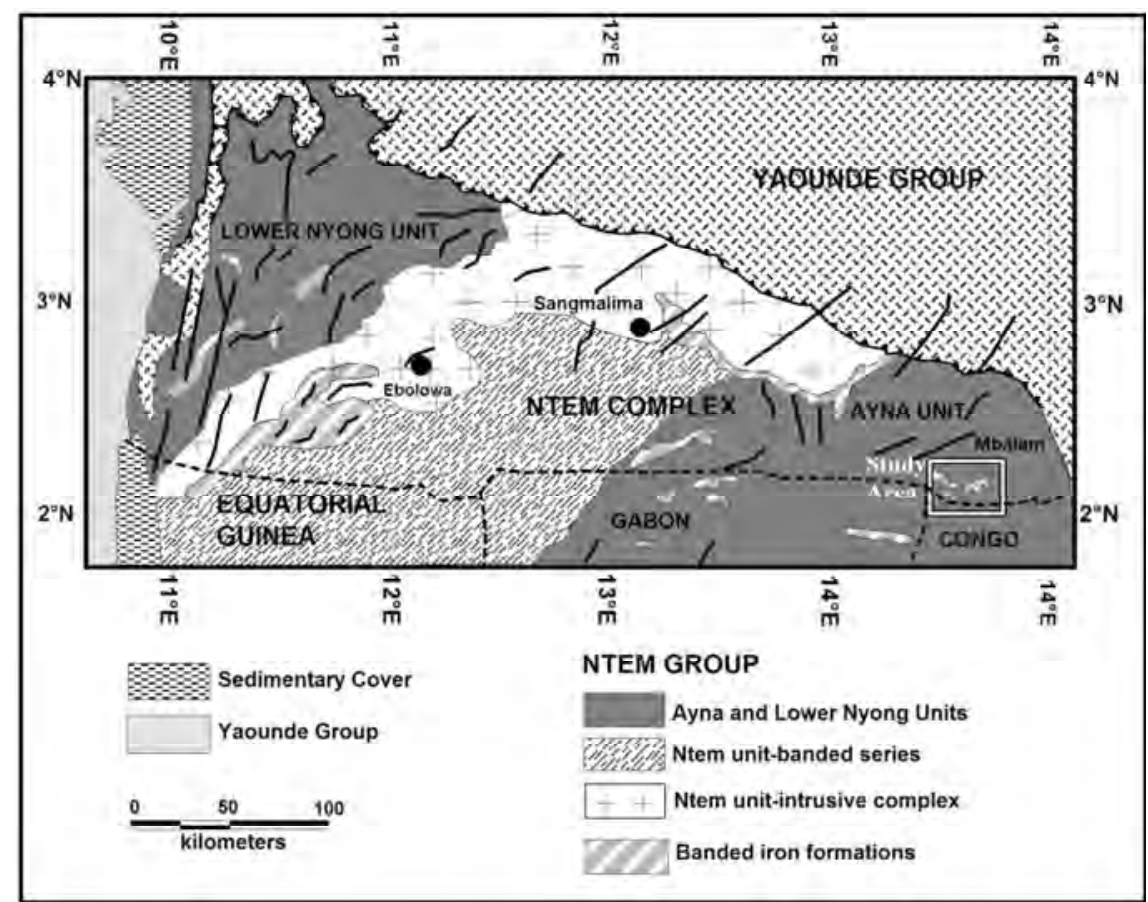

Figure 2. Regional geological map of the northern limit of the Archaean Congo craton (Ntem complex, the Nyong Unit) showing the Mbalam BIF units (study area), late Archean granitic intrusions, and thrust contact with the Pan-African fold belt in Southern Cameroon. (Modified after Maurizot et al., 1986). 
and Djoum-Nkout, respectively, (see www.sundanceresources.com.au, www.afferro-mining.com for details).

\section{Samples and analytical methods}

A total of five (5) samples of rocks collected from cores were used in this study. Among the 5 samples analyzed were four (4) volcanic rock samples occurring as intercalations within the BIFs and one BIF sample. Polished thin sections of the samples were prepared at the Mineral Resources Institute, Technical University of Clausthal, Germany and studied under reflected and transmitted light at the Department of Geology, University of Buea, Cameroon.

Major and trace elements compositions for whole rock analysis were obtained by ICP-OES and ICP-MS at a commercial laboratory (Acme Analytical Laboratories Ltd., Vancouver, Canada). The major elements and several trace elements were reported on a $0.2 \mathrm{~g}$ sample analyzed by ICP-OES following a lithium metaborate/tetrabortate fusion and dilute nitric acid digestion. Loss on ignition (LOI) was determined by weight difference after ignition at $1000^{\circ} \mathrm{C}$. Rare earth and refractory elements were determined by ICP-MS following a similar lithium metaborate/tetrabortate fusion and nitric acid digestion of a $0.2 \mathrm{~g}$ sample. In addition a separate $0.5 \mathrm{~g}$ split was digested in aqua regia and analyzed by ICP-OES to report the precious and base metals. A replicate was done after each analysis for quality control and a standard and a blank run after every 5 samples to calibrate the equipment and ensure optimal precision of the data set obtained.

The volcanic sample, NTV02 and the BIF sample MET510 were dated at the Research School of Earth Sciences (RSES), Australian National University (ANU). Mineral separation was performed in the laboratories of the RSES. The sample was crushed, milled and the fines washed off in a settling beaker. Magnetic minerals were separated using a hand magnet and a Franz isodynamic separator. Heavy minerals were concentrated using both tetrabromoethane and methylene iodide. Concentrated zircons were mounted in epoxy, together with Temora III (416.8 $\pm 1.3 \mathrm{Ma})$, FC1 (1099.1 $\pm 0.5 \mathrm{Ma}$; and SL13 reference zircons. Temora is the primary U-Pb standard, FC1 was used as a secondary standard and to monitor ${ }^{207} \mathrm{~Pb} /{ }^{206} \mathrm{~Pb}$ ratios, and SL13 (Claoué-Long et al., 1995) is a chip of a single crystal with a uniform $\mathrm{U}$ content and is used to calibrate $\mathrm{U}$, Th and $\mathrm{Pb}$ concentrations. The grains were polished to half the thickness of the average grain in the mount to expose any complex internal structures. All zircons were photographed in transmitted and reflected light and these, together with SEM cathodoluminescence images, were used to decipher the internal structures of the sectioned grains and to target specific areas within the zircons for spot analysis. U-Pb analyses were done using SHRIMP RG at the RSES. The data was reduced in a manner similar to that described by Williams (1998) using the SQUID I Excel Macro of Ludwig (2001). The decay constants recommended by the IUGS Subcommission on Geochronology (as given in Steiger and Jäger, 1977) were used in the age calculations. Uncertainties given for individual U-Pb analyses (ratios and ages) are at the 1ä level; however uncertainties in the calculated weighted mean ages are reported as $95 \%$ confidence limits and include the uncertainties in the standard calibrations where appropriate. For the age calculations, corrections for common $\mathrm{Pb}$ were made using the measured ${ }^{204} \mathrm{~Pb}$ and the relevant common $\mathrm{Pb}$ compositions from the model. Concordia plots, regressions and any weighted mean age calculations were carried out using Isoplot/Ex 3.0 (Ludwig, 2003) and, where relevant, include the error in the standard calibration.

\section{Results}

Petrography: The volcanic rocks have twinned plagioclase and K-feldspar porphyroblasts that are subhedral to anhedral in shape within quartz-biotite-sericite groundmass defining a poikiloblastic texture. Biotite and sericite flakes are wrapped around feldspars crystals and they represent secondary mineral phases developed by the alteration of the feldspars (Fig. 3a). Biotite and sericite define a strong mineral lineation while relicts of magmatic flow layering, obscured by the metamorphic overprint are still discernable (Fig. 3b).
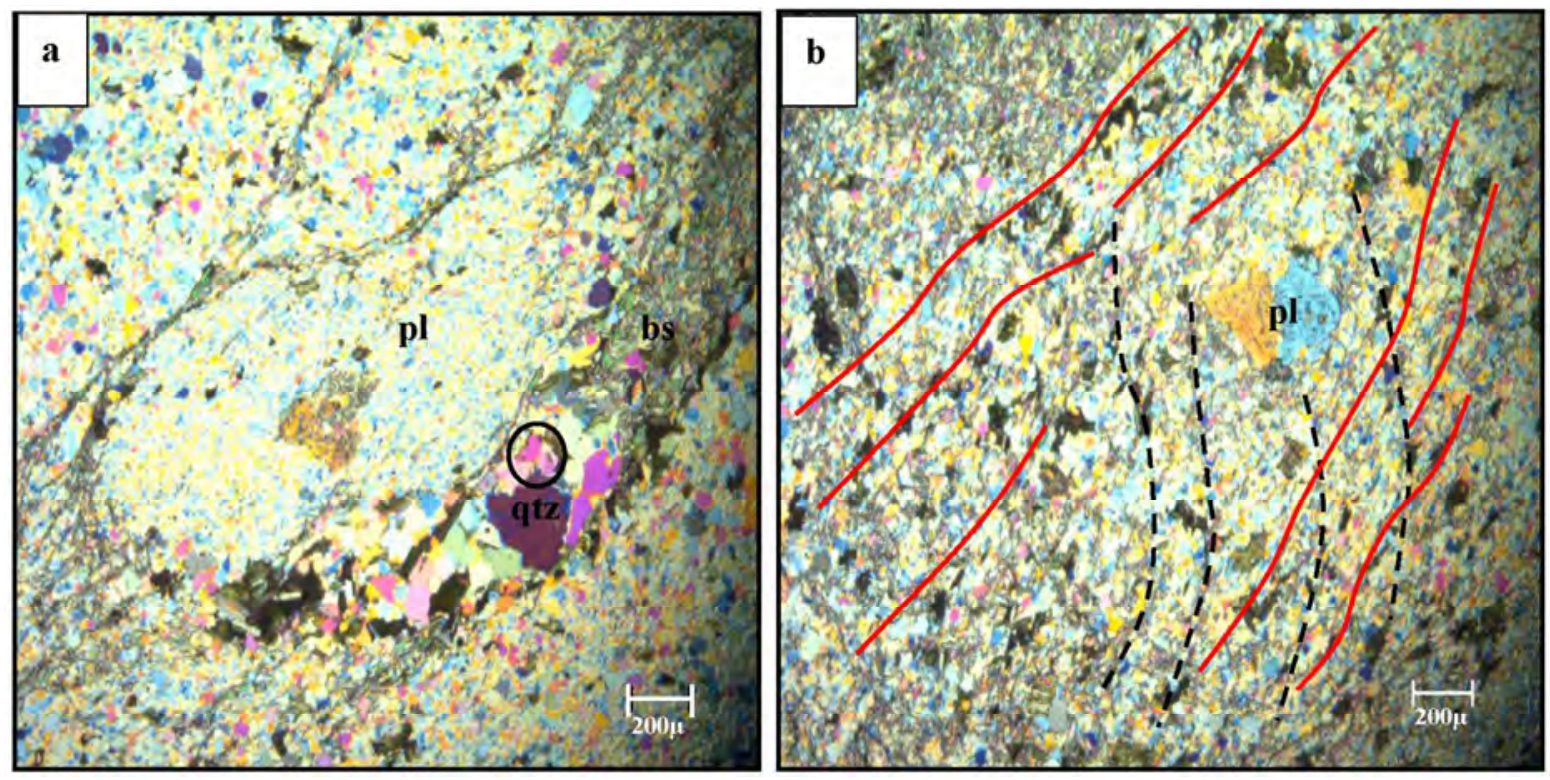

Figure 3. (a) A plagioclase porphyroblast (p) gradually being altered to biotite and sericite (bs).Black circle shows subrounded to polygonal quartz (qtz) crystals defining $120^{\circ}$ grain boundary angle. (b) A Plagioclase porphyroblast (pl) with a quartz-biotite-sericite matrix. Red lines follow strong mineral lineation defined by secondary biotite and sericite phases while black broken lines demarcate original magmatic flow layering. 

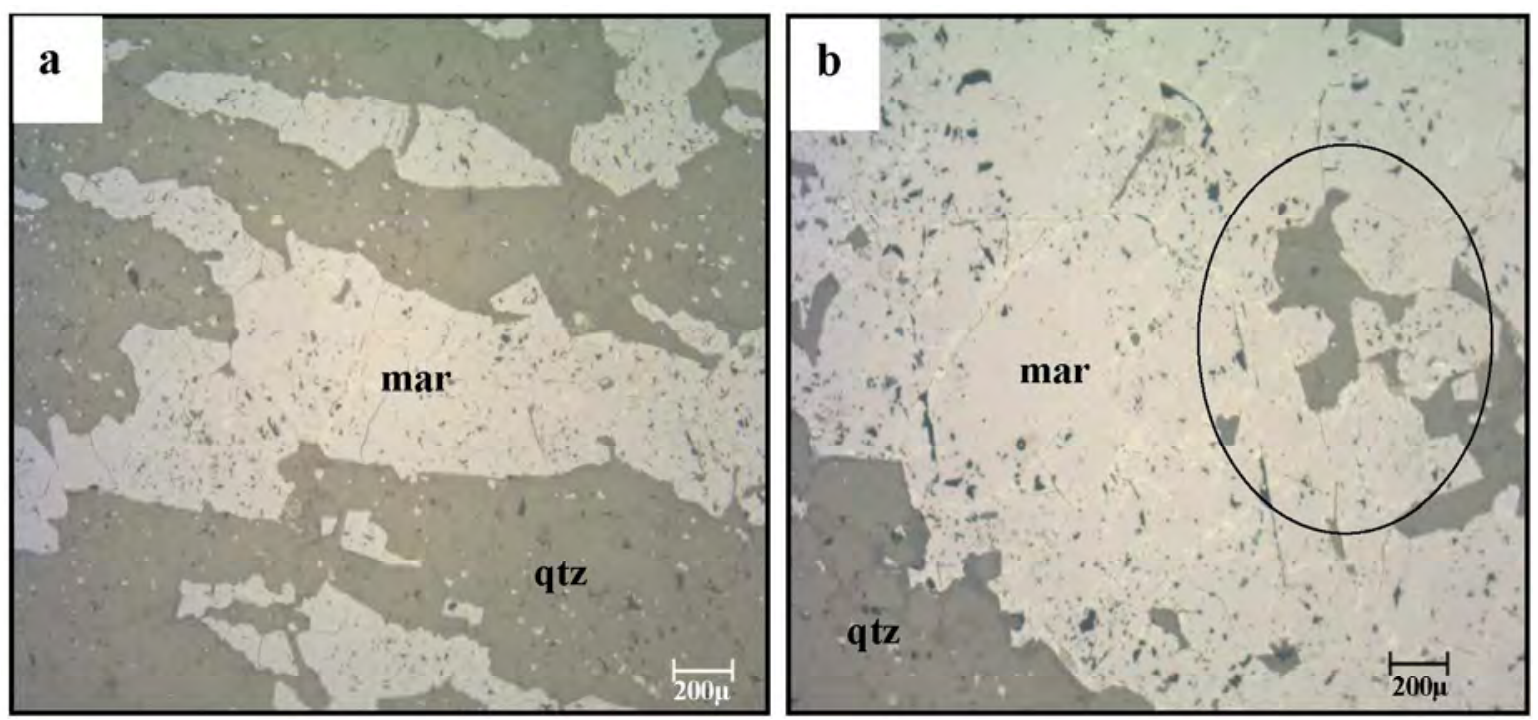

Figure 4. (a) Alternating bands of magnetite and/or martite (mar) with quartz (qtz). (b) Magnetite and/or martite (mar) with lobate grain boundaries defining a granoblastic texture (well expressed within the black circled area)

Quartz crystals are sub-rounded and polygonal with grain boundaries at $120^{\circ}$ angle due to recrystallization (See Fig 3a). This buttresses the metamorphic signature of the samples. Extensive carbonate hydrothermal alteration is indicated by the development of calcite megacrysts. Pyrite, chalcopyrite and pyrrhotite are the main opaque phases and they follow the mineral lineation defined by the phyllosilicates.

The MET510 BIF sample shows alternating bands of quartz and magnetite. The magnetite bands show a gradual transformation to hematite (martitization) (Fig. 4a). Hence, magnetite mainly exists as residual phases in martite and as inclusions within corroded quartz margins. The martite crystals have lobate grain boundaries that build a granoblastic fabric (Fig. 4b). The quartz bands show subhedral polygonal quartz crystals with magnetite and martite filling cavities around corroded quartz margins. The polygonal quartz assembly also defines a granoblastic texture.

\section{Geochemistry}

\section{Major elements}

The volcanic samples have high $\mathrm{SiO}_{2}$ values ranging from 60.9 to $82.09 \mathrm{wt} \%$ expressing the felsic nature of the melt composition. $\mathrm{Na}_{2} \mathrm{O}$ and $\mathrm{K}_{2} \mathrm{O}$ are also of considerable concentrations with values of up to 4.48 and $2.28 \mathrm{wt} \%$, respectively. $\mathrm{MgO}$ and $\mathrm{CaO}$ occur in low concentration but for sample NTV04 with values of $4.5 \mathrm{wt} \%$ and 2.8 wt $\%$, respectively (Table 1). A Total Alkaline Silica plot shows that the samples are rhyolitic (NTV03, NTV02 and NTV05) and dacitic to andesitic (NTV04) in composition (Fig. 5). The MET510 sample has $\mathrm{Fe}_{2} \mathrm{O}_{3}$ value of $50.12 \mathrm{wt} \%$ which is higher than the $20-40 \mathrm{wt} \%$ attributed to $\mathrm{BIF}$ and $\mathrm{SiO}_{2}$ content of $50.25 \mathrm{wt} \%$. Trace elements concentration such as $\mathrm{Rb}, \mathrm{Cs}$, $\mathrm{Hf}$ and Th are generally low. This is typical of quartz-itabirite. Unwanted elements in iron ore such as $\mathrm{Al}_{2} \mathrm{O}_{3}, \mathrm{P}_{2} \mathrm{O}_{5}$ and $\mathrm{S}$ are also low (Table 1) buttressing the high grade iron ore potential of the basin.

\section{Trace and REE data}

Trace elements data from the 5 samples analyzed were normalized against primitive mantle values obtained from Sun and McDonough, (1989). Spidergrams of the normalized data show pronounced negative anomalies for High Field Strength Elements (HFSE) such as Nb, Ta, $\mathrm{Ti}$ and Ho (Fig. 6) while Lithophile Elements (LILE) such as Rb and $\mathrm{Sr}$ are present in high concentrations.

Rare earth elements data of the samples were also normalized against Post Archean Australian Shale (PAAS) values obtained from Nance and Taylor, (1976). Spidergrams of the normalized value for the volcanic samples show a relatively flat pattern of the REE data with the HREE just slightly enriched compared to the LREE (Fig. 7). $(\mathrm{La} / \mathrm{Yb})_{\mathrm{N}}$ values range from 0.559 to 0.842 . The samples have relatively poor REE concentrations with $\Sigma$ REE ranging from 7.725 to 11.322. All the REE but for Eu show a flat to gentle pattern. Sample NTV03 and NTV05 show a negative Eu anomaly as reflected in their $\mathrm{Eu} / \mathrm{Eu}^{*}$ value of 0.623 and 0.675 , respectively. NTV04 show a weak positive Eu anomaly while NTV02 presents a weak negative to flat Eu pattern.

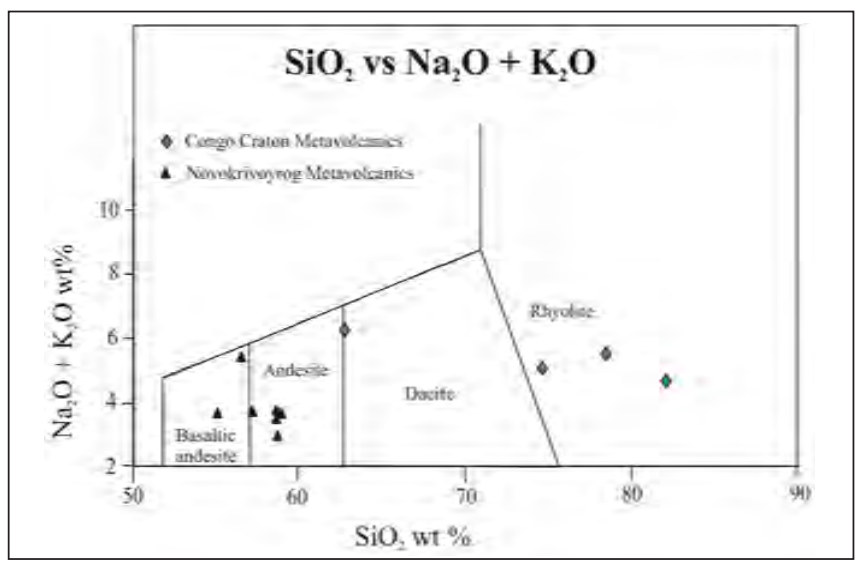

Figure 5. Total Alkali Silica Plot of the metavolcanic samples from the Congo Craton. Note the more basic nature of the Novokrivoyrog metavolcanics compared to the Congo Craton Metavolcanics. A close similarity is however observed between the two cratons as expressed by the dacitic to andesitic sample of the Congo Craton. Novokrivoyrog metavolcanic samples obtained from Mboudou et al. (2012, in press). 
Table 1. Chemical composition of metavolcanic samples (NTV02 - 05) and BIF sample (MET510) from the northern edge of the Congo craton examined in this study

\begin{tabular}{|c|c|c|c|c|c|}
\hline Samples & NTV02 & NTV03 & NTV04 & NTV05 & MET510 \\
\hline \multicolumn{6}{|c|}{ Major elements, wt\% } \\
\hline $\mathrm{SiO}_{2}$ & 74.63 & 78.5 & 62.9 & 82.09 & 50.25 \\
\hline $\mathrm{Al}_{2} \mathrm{O}_{3}$ & 12.98 & 11.81 & 14.87 & 9.35 & 0.25 \\
\hline $\mathrm{Fe}_{2} \mathrm{O}_{3}$ & 3.24 & 1.5 & 6.3 & 1.66 & 50.12 \\
\hline $\mathrm{MgO}$ & 0.86 & 0.51 & 4.5 & 0.56 & $<0.01$ \\
\hline $\mathrm{CaO}$ & 1.71 & 0.86 & 2.8 & 0.61 & 0.02 \\
\hline $\mathrm{Na}_{2} \mathrm{O}$ & 3 & 4.48 & 3.88 & 3.49 & 0.01 \\
\hline $\mathrm{K}_{2} \mathrm{O}$ & 1.99 & 0.92 & 2.28 & 1.11 & 0.01 \\
\hline $\mathrm{TiO}_{2}$ & 0.22 & 0.09 & 0.63 & 0.07 & $<0.01$ \\
\hline $\mathrm{P}_{2} \mathrm{O}_{5}$ & 0.04 & 0.02 & 0.15 & 0.02 & 0.07 \\
\hline $\mathrm{MnO}$ & 0.06 & 0.02 & 0.11 & 0.03 & 0.02 \\
\hline $\mathrm{Cr}_{2} \mathrm{O}_{3}$ & $<0.002$ & $<0.002$ & 0.014 & $<0.002$ & $<0.002$ \\
\hline $\mathrm{Ni}$ & $<20$ & $<20$ & 108 & $<20$ & $<20$ \\
\hline $\mathrm{Sc}$ & 5 & 3 & 18 & 3 & 2 \\
\hline TOT/C & 0.07 & $<0.02$ & 0.05 & 0.12 & $<0.02$ \\
\hline TOT/S & 0.16 & 0.1 & 0.04 & $<0.02$ & $<0.02$ \\
\hline LOI & 1.1 & 1.2 & 1.4 & 1 & -0.7 \\
\hline Sum & 99.87 & 99.95 & 99.82 & 99.97 & 99.99 \\
\hline
\end{tabular}

Trace elements, ppm

$\begin{array}{lll}224 & 472 & 189\end{array}$

$<1$

$\begin{array}{rrr}<1 & <1\end{array}$

29

5.7

6.2

2

122.8

0.5

3.8

1

$<0.5$

147.6

20.2

15.4

36.2

4.24

16.9

3.35

0.91

3.48

0.58

3.47

0.73

2.18

0.31

2.03

0.32

0.4

59.7

2

73

101.6

1
$<0.1$

$<0.1$

0.2

$<0.1$

$<0.5$

0.01

$<0.5$
14.6

Hf 4

$\mathrm{Nb} \quad 7.7$

Ta

m

$\mathrm{Eu}$

Gd

$\mathrm{Tb}$

Dy

$\mathrm{Er}$
$\mathrm{Tm}$

$\mathrm{Yb}$

$\mathrm{Lu}$

Mo

$\mathrm{Cu}$

$\mathrm{Zn}$

As

$\mathrm{Cd}$

$\mathrm{Sb}$

$\mathrm{Bi}$

Ag

$\mathrm{Au}$

$\mathrm{Hg}$

Tl

1.3

11.2

4.5

7.6

40.2

2

97.2

0.7

8.9

2.5

$<8$

$<0.5$

132.9

25.3

28.1

56.4

6.05

21.5

4.29

0.57

4.24

0.71

4.12

0.9

2.52

0.38

2.46

0.38

63.9

24

89

7.1

1.3

0.4

$<0.1$

0.3

0.3

$<0.5$

0.02

0.3

$<0.5$

$<0.1$

1.1

$<0.1$

0.3

0.6

$<1$

4.1

$<0.1$

0.4

0.

$<0.5$

8.5

16.5

5.9

12.8

1.79

7.3

1.56

0.62

1.75

0.31

2.04

0.49

1.48

0.22

1.42

0.23

1.9

2

1.8

1.4

$<0.1$

$<0.1$
$<0.1$

$<0.1$

$<0.1$

$<0.5$

0.01

$<0.1$

$<0.5$

NTV02 - NTV05 are volcanic materials intercalated with BIFs, MET510- a BIF sample (samples are cores obtained within the Ntem Complex at the northern edge of the Congo Craton)

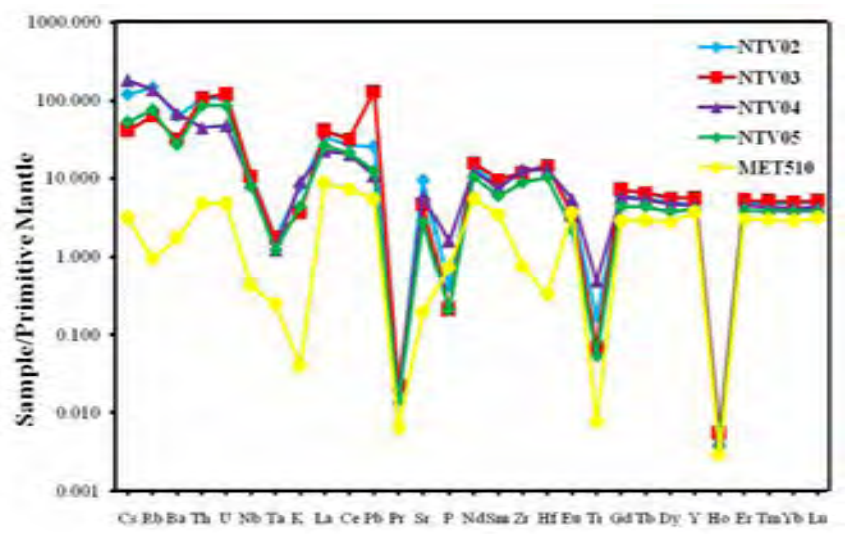

Figure 6. Primitive Mantle normalized trace elements and rare earth element plot. NTV02 - 05 (represents metavolcanic samples), MET510 (BIF sample). Note the negative peaks of $\mathrm{Nb}, \mathrm{Ta}, \mathrm{Ti}$ and Ho expressing the arc magmatic origin of the metavolcanic samples

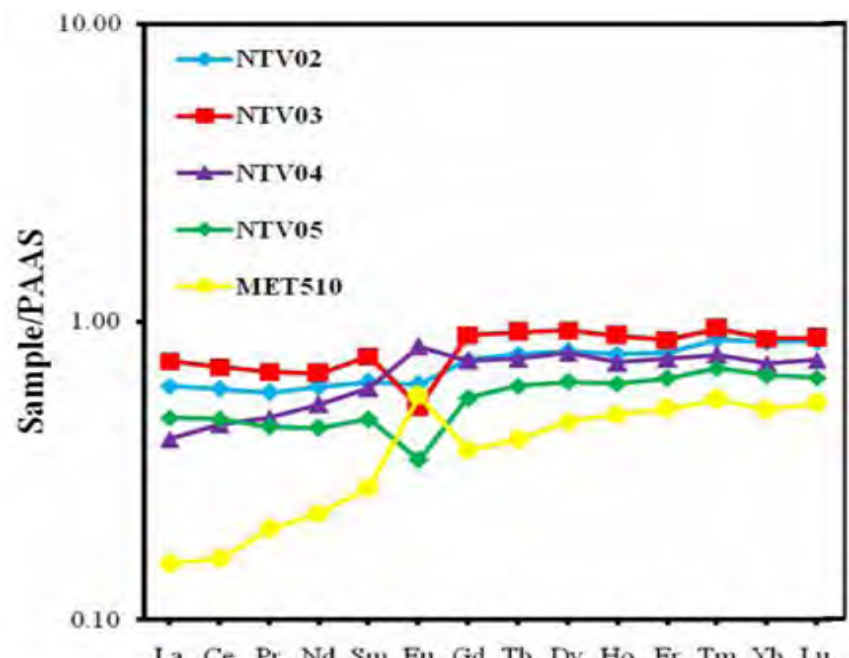

Figure 7. PAAS normalized rare earth elements plot. NTV02 - 05 (represents metavolcanic samples), MET510 (BIF sample). Note the similarity in pattern and positive Eu anomalies of NTV04 and the MET510 sample expressing the pristine nature of sample NTV04.

The MET510 sample shows HREE enrichment over the LREE with positive Eu anomaly. Ce shows a very weak negative anomaly to flat pattern probably influenced by similar poor concentrations of La and Pr. The $\Sigma$ REE is low with a value of 5.418.

\section{Geochronology}

The sample NTV02 that was dated in this study is intercalated with BIF deposits in the Ntem Complex at the northern limit of the Congo craton. The geochronology results are summarized in Table 2 and Fig. 8. Unfortunately, the volcanics have very few zircon grains. Four zircons were found in the heavy mineral separate from the rock. All are brown and euhedral to subhedral in form. Cathodoluminescence imaging (Fig. 8) shows magmatic oscillatory zoning with varying intensity and scale. These zircons lack internal resorption features and serrated zone boundaries as should be expected of zircons inherited from the surrounding basement rocks. Features of inherited zircons such as patchy wavy extinction and differential deformation 
Table 2. Summary of SHRIMP U-Pb zircon data for sample 117 and MET510

\begin{tabular}{|c|c|c|c|c|c|c|c|c|c|c|c|c|c|c|c|}
\hline $\begin{array}{l}\text { Grain } \\
\text { Spot }\end{array}$ & $\begin{array}{c}{ }^{206} \mathrm{~Pb}_{\mathrm{c}} \\
\%\end{array}$ & $\begin{array}{c}\mathrm{U} \\
\mathrm{ppm}\end{array}$ & $\begin{array}{c}\text { Th } \\
\text { ppm }\end{array}$ & ${ }^{232} \mathrm{Th} /{ }^{238} \mathrm{U}$ & $\begin{array}{c}{ }^{206} \mathrm{~Pb}^{*} \\
\mathrm{ppm} \\
\text { Age }\end{array}$ & $\begin{array}{c}(1) \\
{ }^{206} \mathrm{~Pb} /{ }^{238} \mathrm{U} \\
\text { Age }\end{array}$ & $\begin{array}{c}(1) \\
{ }^{207} \mathrm{~Pb} /{ }^{206} \mathrm{~Pb}\end{array}$ & $\begin{array}{c}\text { Discordant } \\
\%\end{array}$ & ${ }^{207} \mathrm{~Pb}^{*} /{ }^{206} \mathrm{~Pb}^{*}$ & $\pm \%$ & $\begin{array}{c}(1) \\
{ }^{207} \mathrm{~Pb}^{*} / 235 \mathrm{U}\end{array}$ & $\pm \%$ & $\begin{array}{c}(1) \\
{ }^{206} \mathrm{~Pb}^{*} / 238 \mathrm{U}\end{array}$ & $\pm \%$ & $\begin{array}{l}\text { Error } \\
\text { corr }\end{array}$ \\
\hline \multicolumn{16}{|c|}{ Sample 117} \\
\hline 2.1 & 0.03 & 144 & 66 & 0.47 & 69 & $2851 \pm 32$ & $2873.4 \pm 5.5$ & 1 & 0.2058 & 0.34 & 15.79 & 1.4 & 0.5563 & 1.4 & .973 \\
\hline 3.1 & 0.00 & 177 & 143 & 0.83 & 80.3 & $2737 \pm 26$ & $2889 \pm 16$ & 5 & 0.2079 & 0.98 & 15.16 & 1.5 & 0.5289 & 1.2 & .762 \\
\hline 4.1 & 0.03 & 355 & 236 & 0.69 & 168 & $2828 \pm 46$ & $2894.7 \pm 3.6$ & 2 & 0.2086 & 0.22 & 15.84 & 2 & 0.551 & 2 & .994 \\
\hline 2.2 & 0.06 & 125 & 88 & 0.73 & 50.7 & $2494 \pm 47$ & $2894.1 \pm 9$ & 14 & 0.2085 & 0.56 & 13.58 & 2.3 & 0.472 & 2.3 & .972 \\
\hline 3.2 & 0.11 & 157 & 120 & 0.79 & 66.3 & $2579 \pm 26$ & $2890 \pm 30$ & 11 & 0.208 & 1.9 & 14.11 & 2.2 & 0.4919 & 1.2 & .548 \\
\hline \multicolumn{16}{|c|}{ Sample MET 510} \\
\hline 1.1 & 0.00 & 40 & 14 & 0.36 & 7.14 & $1204 \pm 19$ & $1288 \pm 30$ & 7 & 0.0838 & 1.5 & 2.372 & 2.3 & 0.2053 & 1.7 & .741 \\
\hline 1.2 & 0.43 & 47 & 17 & 0.38 & 7.64 & $1117 \pm 18$ & $1157 \pm 50$ & 3 & 0.0784 & 2.5 & 2.045 & 3.1 & 0.1892 & 1.7 & .567 \\
\hline 2.1 & 0.04 & 185 & 93 & 0.52 & 35 & $1280 \pm 15$ & $1358 \pm 14$ & 6 & 0.08688 & 0.73 & 2.63 & 1.5 & 0.2196 & 1.3 & .874 \\
\hline 2.2 & 0.24 & 174 & 91 & 0.54 & 26.3 & $1045 \pm 13$ & $1244 \pm 24$ & 16 & 0.08196 & 1.2 & 1.989 & 1.8 & 0.176 & 1.3 & .733 \\
\hline 3.1 & 0.10 & 196 & 99 & 0.52 & 29.3 & $1034 \pm 12$ & $1027 \pm 18$ & -1 & 0.07346 & 0.91 & 1.762 & 1.6 & 0.174 & 1.3 & .810 \\
\hline
\end{tabular}

Errors are 1-sigma; $\mathrm{Pb}_{\mathrm{c}}$ and $\mathrm{Pb}^{*}$ indicate the common and radiogenic portions, respectively. Error in Standard calibration was $0.27 \%$ (not included in above errors but required when comparing data from different mounts). (1) Common $\mathrm{Pb}$ corrected using measured ${ }^{204} \mathrm{~Pb}$.

lamellae are also absent. These zircons are therefore magmatic in origin. Five analyses were done on 3 grains. The data show variable discordance and some scatter (see Fig. 9) but as a group do give a weighted mean ${ }^{207} \mathrm{~Pb} /{ }^{206} \mathrm{~Pb}$ age of $2889 \pm 13 \mathrm{Ma}(\mathrm{MSWD}=2.7$; probability $=0.028$ ). Similarly, an upper intercept age of $2883 \pm 20$ Ma was calculated, but the high MSWD and low probability of 0.025 reflect the scatter in the data which is attributed to the magma residence time and zircon growth prior to eruption. This has been quantified (Brown and Fletcher, 1999) to be in the order of hundreds of thousands of years. This also explains the large error margin in the data.

A surface BIF sample $\sim 60 \mathrm{~km}$ west of the area where the metavolcanics were sampled (MET510) was also dated. The zircons in this sample are small $(<150 \mu \mathrm{m}$ in the longest dimension $)$ and show little internal structure, even with the aid of SEM cathodoluminescence imaging, apart from grain \#4 (Fig. 10) that has a small dark-CL rim and faint zoning. The oldest zircon in this sample is \#4 and the single analysis of this grain is slightly discordant but gives a ${ }^{207} \mathrm{~Pb} /{ }^{206} \mathrm{~Pb}$ age of $2057 \pm 10 \mathrm{Ma}$. The remaining analyses show far more complexity and spread along or near the concordia

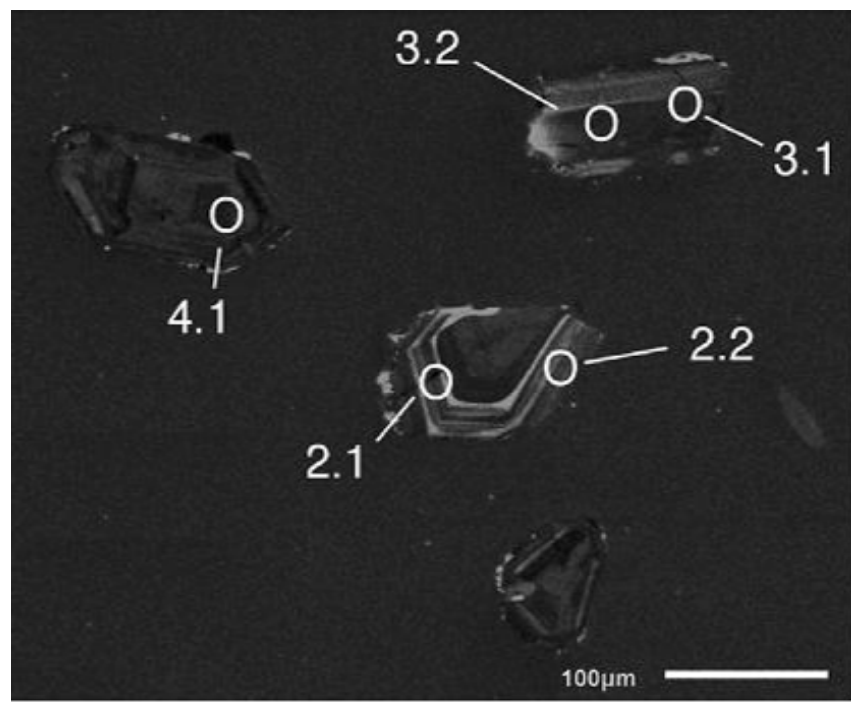

Figure 8. Cathodoluminescence image of a selection of the zircons analyzed from sample 117. The numbered ellipses mark the spots analyzed. curve with what appears to be variable ages. Three of the 4 analyses are clearly discordant, but analysis 3.1 is concordant within error, giving an apparent age of $\sim 1030 \mathrm{Ma}$. The ${ }^{207} \mathrm{~Pb} /{ }^{206} \mathrm{~Pb}$ "ages" on the other analyses range from 1157 to $1358 \mathrm{Ma}$ (Table 2 and Fig. 10 summarize the geochronological data).

\section{Discussion and conclusions}

\section{Major, trace elements and REEs}

The negative peaks of $\mathrm{Nb}, \mathrm{Ta}, \mathrm{Ti}$ and Ho shown by the studied metavolcanics on the trace element spidergram (see Fig. 6) suggests that they crystallized from arc magma. Similarly, their high $\mathrm{Rb}$ and Sr concentrations are also indicative of a back arc environment (Elburg, 2010). Mantle plumes have been shown to be the major Fesource of BIF deposits (Konhauser et al., 2007b and Steinhoefel et al., 2010). Economic scale BIF deposition therefore has a direct bearing with volcanic activity. The chemical composition of the mantle plume is a useful tool in determining its source region and depositional milieu of associated BIF deposits. The tectonic evolution of the Ntem Complex has before now identified 3 phases of magmatic

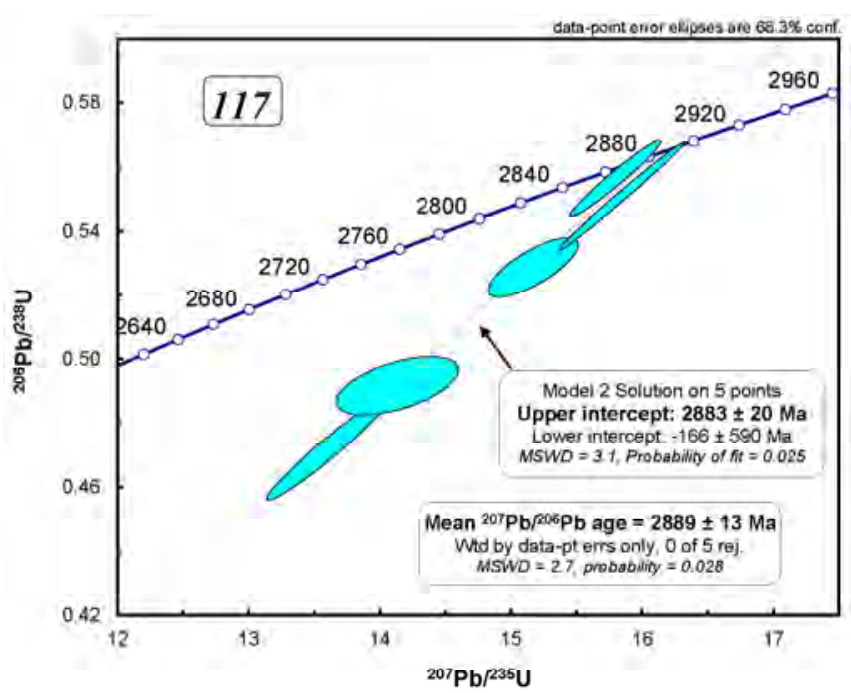

Figure 9. U-Pb concordia plot of all zircon data from sample 117. 


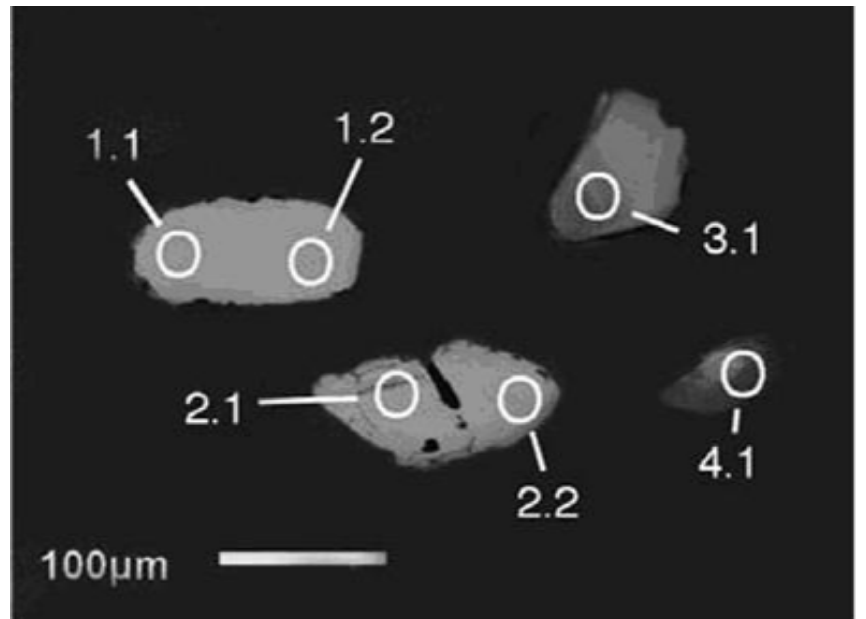

Figure 10. Cathodoluminescence image of zircons separated and analyzed from sample MET510. The numbered ellipses mark the spots analyzed.

emplacement (Owona, 2008) with the arc magmatic concept invoked for the emplacement of the Ebolowa metasyenites between 33633106Ma (Tchameni et al., 2001) and the Makoukou BIFs between $3091 \pm 13 \mathrm{Ma}$. A continental arc setting has been favoured over an island arc setting for the emplacement of these units based on the chemistry of the lithologies analyzed. The rhyolitic, dacitic to andesitic nature of the volcanic samples suggest an originally acidic melt composition which is typical of continental arc margins. It is true that crustal contamination and mixing are all possible mechanisms for inducing chemical variations in arc magmas (Elburg, 2010) but the petrography and geochemistry of our samples support a simple fractional crystallization model to be responsible for the development of the various intercalated volcanics within BIFs in the Congo Craton. This is supported by the absence of common features of mixing such as magmatic enclaves and xenomorphic inclusions in the polished sections. Crustal contamination features such as entrained fragments and inversed zoning are equally absent. Rather the samples show similar chemical characteristics with variations in their silica content and their REE pattern which we attribute to crystal fractionation with subtle post emplacement alteration. The weak HREE/LREE expressed by $(\mathrm{La} / \mathrm{Yb})_{\mathrm{N}}$ values generally $<1$ is attributed to an originally basaltic to andesitic magmatic melt in which all the REEs were incompatible in crystallizing mineral phases such as olivine, orthopyroxene and clinopyroxene. However, the $\Sigma$ REE between 7.725 and 11.322 shows that the original magma source was probably also poor in the REEs. The positive Eu-anomaly of sample NTV04 (a similar pattern to that of MET510) shows the pristine nature of the sample compared to the others with less altered plagioclase minerals. The presence of Naamphiboles and hornblende could account for the slight enrichment of the HREE/LREE in this sample compare to the MET510.

$\mathrm{Fe}_{2} \mathrm{O}_{3}$ and $\mathrm{SiO}_{2}$ content of $20-40 \mathrm{wt} \%$ and $43-56$ wt \%, respectively are typical of BIF deposits (Klein, 2005). The higher Fe content $(50.12 \mathrm{wt} \%)$ of the MET510 sample is indicative of the gradual replacement of silica with Fe through leaching reflected by the corroded quartz margins and cavities within the quartz bands filled by magnetite and/or martite (Fig. 4). Such features have earlier been described (Suh et al., 2008) in the Ntem Complex for the Metzimevin itabirites and were attributed to hydrothermal activity. However, the lack of hydrothermal particularities such as hematite specularites

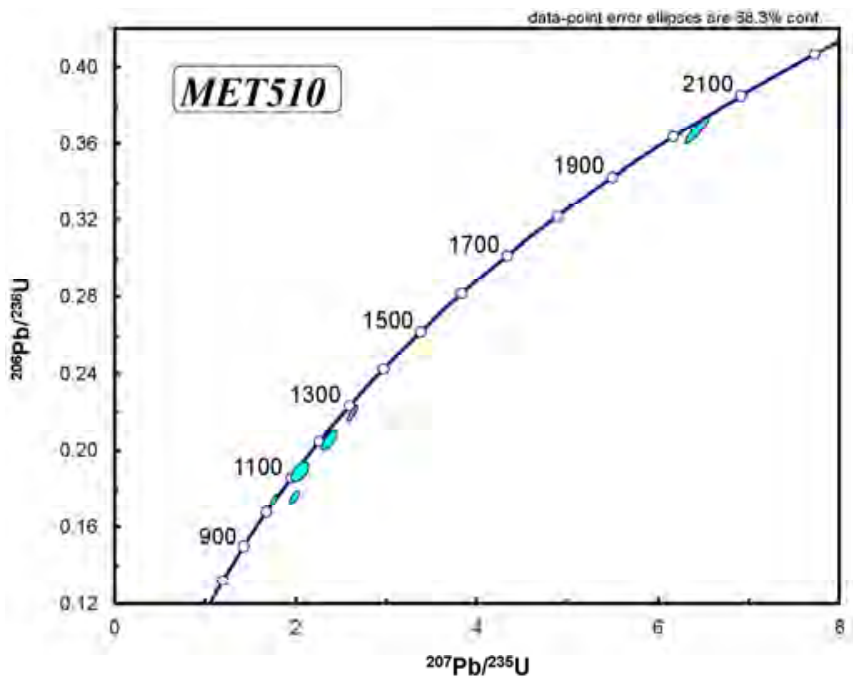

Figure 11. U-Pb concordia plot of zircon data from the BIF MET510

(Powell et al., 1999 and Cabral et al., 2003) suggests supergene processes. Hence, both processes are feasible in the development of high grade iron ores within the Congo Craton.

Marine signatures in BIF deposits are better expressed by their REE patterns (Derry et al., 1990; Frei and Polat, 2007). MET510, the BIF sample analyzed together with the volcanics in this study show a clear and distinct HREE enrichment over the LREE with a positive Eu anomaly typical of Precambrian marine BIF deposits (Derry et al., 1990; Alibert and McCulloch, 1992). HREE enrichment over the LREE in sea water is controlled by an effect known as lanthanide contraction whereby the HREE have a greater affinity to particle surfaces compared to the LREE, due to their small ionic sizes. Positive Eu-anomaly has been widely attributed to hydrothermal sources (Derry et al., 1990; Frei and Polat, 2007). A negative Ce anomaly is also a key indicator of modern sea water. However, the weakly negative to flat pattern of Ce for the MET510 sample may simply be explained by the poor concentrations of La and Pr. Though $\mathrm{La}$ and Pr may account for this, dilution of the sea sediments by river influx may also account for the very weak negative Ce-anomaly (German et al., 1991). Such influx also boosts the positive Euanomalies in sea sediments evident for this sample.

\section{Geochronology}

$\mathrm{Th} / \mathrm{U}$ ratio and zircon morphologies are used to distinguish magmatic zircons from xenocrystic and metamorphic zircons. However, the $\mathrm{Th} / \mathrm{U}$ ratio has been criticized by some authors owed to the fact that the evaluated $\mathrm{Th} / \mathrm{U}$ ratio of $>0.1$ for magmatic zircons have been recorded in zircons from other sources (Schaltegger et al., 1999; Rubatto, 2002; Möller et al., 2003 and Harley et al., 2007). The clear oscillatory zoning of the zircons in this study reflects their magmatic origin. The ${ }^{207} \mathrm{~Pb} /{ }^{206} \mathrm{~Pb}$ age of $2883 \pm 20 \mathrm{Ma}$ obtained for the dacite sample (NTV02) in this study is interpreted as the age of crystallization of the dacite and directly constraints the age of initial BIF deposition in the Ntem Complex at the northern edge of the Congo Craton. With no distinct evidence of metamorphic zoning on the zircons, the minor scatter in the data set is attributed to magma residence time and zircon growth prior to eruption (Brown and Fletcher, 1999). Therefore, the U-Pb concordant ages effectively date the age of eruption of the dacite. The ${ }^{206} \mathrm{~Pb} /{ }^{238} \mathrm{U}$ age window between 
$2494 \pm 47 \mathrm{Ma}$ and $2851 \pm 32 \mathrm{Ma}$ compare similarly with crystallization ages of $2768 \pm 16 \mathrm{Ma}$ and $2766 \pm 3 \mathrm{Ma}$ obtained for dacites and rhyolites at the lower BIF succession of the Hamersley Province in northwestern Australia. Similarly, Sumner and Bowring (1996) obtained ages of $2521 \pm 3 \mathrm{Ma}$ on volcanic ash beds of the Campbellrand Subgroup, Transvaal Supergroup, South Africa and interpreted these ages to constrain the age of deposition of the Kuruman. Griquatown and Penge iron formations. Also, in the Minas Supergroup, Quadrilatero ferrifero Brazil, recent $\mathrm{U}-\mathrm{Pb}$ ages of $2.65 \mathrm{Ga}$ have been reported on zircon obtained from a metavolcanic layer within the Caué Itabirite Formation (Cabral et al., 2012). This age confirms early SHRIMP U-Pb ages of 2750Ma obtained on zircons (from metarhyolites) by Trendall et al., (1998) on the Carajás formations in the Minas Supergroup. The above ages fall within the $2883 \pm 20 \mathrm{Ma}$ window obtained in this study for BIF deposition as in the Congo Craton. These age similarities suggest a regional period of magmatic emplacement in the Hamersley Basin, Transvaal, Quadrilatero Ferrifero and the Congo craton associated with BIF deposition as earlier suggested by Trendall et al. (2004) and revisited by Beukes and Gutzmer (2008). Age comparative summaries of these world class iron ore hosted basins to the Congo Craton are summarized in Appendices 1 and 2.

Though the volcanic sample largely gives an Archean age of BIF deposition within the Congo Craton, geochronological data on the BIF sample (MET510) collected on the surface give much younger ages that are typically Eburnean. Earlier reported Eburnean ages similar to that obtained from zircon \#4 (between 2400 and 1800Ma) by $\mathrm{Rb}-\mathrm{Sr}$ on whole rock within the Ntem Complex were attributed to $\mathrm{Pb}$-loss during the reactivation events within the unit. Shang et al. (2004a) reported ages between 2299 and 2064Ma by Rb-Sr on biotite within the Ntem Complex buttressing the Eburnean reactivation of the Congo Craton. More recently, Shang et al. (2010) reported zircon $\mathrm{U}-\mathrm{Pb}$ ages between 2098 and $2465 \mathrm{Ma}$ on the charnockitic suite in the Sangmelima area and largely favored $\mathrm{Pb}-$ loss by diffusion and leaching as the main causative factor of the young ages. Though the above authors largely favor $\mathrm{Pb}$-loss in their interpretation of the Eburnean ages, the nature of the zircons observed in MET510 and the wide variation in the data set suggest a more complex mechanism rather than just Pb-loss. Anderson (1978) had shown that diagenetic brines often contain $>10 \mathrm{ppm} \mathrm{Pb}$ thus a small amount of such fluid can alter the $\mathrm{Pb}$-isotopic signature and decrease the $\mathrm{U} / \mathrm{Pb}$ or increase the $\mathrm{Pb} / \mathrm{U}$ ratio within rocks. The identification of carbonate minerals on some polished sections of the metavolcanics samples obtained in association with the BIF sample (MET510) are attributed to basinal brines. This suggests the possibility of diagenetic brines within the unit. Therefore the influence of Pb-loss in the sample should have been limited by $\mathrm{Pb}$ incorporation in the system from basinal brines hence the variations in the data set should be limited. We therefore attribute these variable zircon ages to a more recent phase of BIF deposition in the Ntem complex which has been unrecognized heretofore.

Although the ${ }^{207} \mathrm{~Pb} /{ }^{206} \mathrm{~Pb}$ age of $2883 \pm 20 \mathrm{Ma}$ represents the age of BIF deposition in the Congo Craton, the exact onset of BIF deposition within this basin is still questionable. Caen-Vachette (1988) have earlier mentioned the deposition of the Makoukou BIFs at 3091 \pm 13 Ma suggesting that the basin must have been opened earlier and remained as an open system for long period. Hence, the $2883 \pm 20 \mathrm{Ma}$ probably represents the age of maximum BIF deposition within the Congo Craton. This age compares closely to wide spread intrusive emplacement ages within the Congo Craton notably the Sangmelima

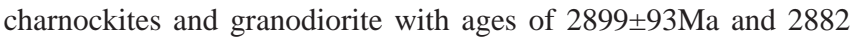
$\pm 28 \mathrm{Ma}$ respectively (Shang et al., 2007). This emplacement has been described (Owona, 2008) as a $3^{\text {rd }}$ Phase (E3) intrusive emplacement within the Congo Craton.

\section{Acknowledgement}

This paper is part of the $\mathrm{PhD}$ thesis of Nelson Chombong underway at University of Buea and undertaken within the collaboration framework between the University of Buea and TU Clausthal, Germany, sponsored by the Alexander von Humboldt Foundation (AvH Stiftung) and coordinated by Prof. Bernd Lehmann to whom we are most grateful. The authors thank R. Armstrong and M. Fanning for the zircon dating. Manuscript benefitted from comments from Alexandre Cabral of TU Clausthal.

\section{References}

Alibert, C. and McCulloch, M.T., 1992 Rare earth element and neodymium isotopic compositions of the banded iron formations and associated shales from Hamersley, Western Australia. Geochimica et Cosmochimica Acta, v. 57 , pp. $187-204$.

Anderson, G.A., 1978, Basinal brines and Mississippi Valley-type ore deposits. Episodes, pp. 15-19.

Bau, M. and Möller, P., 1993, Rare earth element systematics of the chemical precipitated component in Early Precambrian iron formations and the evolution of the terrestrial atmosphere-hydrosphere-lithosphere system. Geochimica et Cosmochimica Acta, v. 57, pp. 2239-2249.

Bekker, A., Holland, H., Wang, P.L., Rumble, D., Stein, H., Hannah, J., Coetzee, L. and Beukes, J.J., 2004, Dating the rise of atmospheric oxygen. Nature, v. 427, pp. 117-120.

Beukes, N.J. and Gutzmer, J., 2008, Origin and Paleoenvironmental Significance of Major Iron Formations of the Archean-Paleoproterozoic Boundary. Economic Geology Reviews, v. 15, pp. 5-47.

Blake, T.S., Buick, R., Brown, S.J.A. and Barley, M.E., 2004, Geochronology of Late Archean flood basalt in the Pilbara Craton, Australia: constraints on basin evolution, volcanic and sedimentary accumulations, and continental drift rates. Precambrian Research, v. 133, pp. 143-173.

Brown, S.J.A. and Fletcher, I.R., 1999, SHRIMP U-Pb dating of pre-eruption growth history of zircons from the 340Ka Whakamaru Ignimbrite, New Zealand: evidence for $>250 \mathrm{Ka}$ magma residence times. Geology, v. 27, pp. 1035-1038.

Cabral, A.R., Rocha Filho, O.G. and Jones, R.D., 2003, Hydrothermal origin of soft hematite ore in the Quadrilátero Ferrifero of Minas Gerais, Brazil: Petrographic evidence from the Gongo Socco iron ore deposit. Applied Earth Science (Transactions of the Institute of Mining and Metallurgy Section B), v. 112, pp. 279-286.

Cabral, A.R., Zeh, A., Koglin, N., Gomes Jr., A.A. S., Viana, D.J. and Lehmann, B., 2012, Dating the Itabira rion formation,Quadrilátero Ferrífero of Minas Gerais, Brazil, at 2.65Ga: Depositional U-Pb age of zircon from a metavolcanic layer. Precambrian Research, v. 204-205, pp. 40-45.

Caen-Vachette, M., Vialette, Y., Bassot, J.P., and Vidal, P., 1988, Apport de la geochronology à la connaissance de la géologie gabonaise. Chron. Rech. Min. No. 491, pp. 35-54.

Claoué-Long, J.C., Compston, W., Roberts, J. and Fanning, C.M., 1995, Two Carboniferous ages: a comparison of SHRIMP zircon dating with conventional zircon ages and ${ }^{40} \mathrm{Ar} /{ }^{39} \mathrm{Ar}$ analysis. In: Geochronology, Time Scales and Global Stratigraphic Correlation, Berggen, W.A. Kent, D.V. Aubry, M.P. and Hardenbol, J. (eds.), SEPM Special Publication, v. 4, pp.3-21.

Clout, J.M.F. and Simonson, B.M., 2005, Precambrian iron formations and iron formations-hosted iron ore deposits. Economic Geology, v. 100, pp. 643-679.

Derry, L.A. and Jacobsen, S.B., 1990, The chemical evolution of Precambrian 
seawater: Evidence from REEs in banded iron formations. Geochimica et Cosmochimica Acta, v. 54, pp. 2965-2977.

Frei, R. and Polat, A., 2007, Source heterogeneity for major components of 3.7Ga Banded Iron Formations (Isua Greenstone Belt, Western Greenland): Tracing the nature of interacting water masses in BIF formations. Earth and Planetary Science Letters, v. 253, pp. 266-281.

Elburg, M.A., 2010, Source and processes in arc magmatism: the crucial role of water. An inaugural lecture to the society. Geologica Belgica, v. 13/3, pp. 121-136.

Feybesse, J.L., Johan, V., Triboulet, C., Guerrot, C. Mayaga-Mikolo, F., Bouchot, V. and Eko N'dong, J., 1998, The West Central African belt: a model of 2.5-2.0Ga accretion and two-phase orogenic evolution. Precambrian Research, v. 87, pp.161

Fischer, W.W. and Knoll, A.H., 2009, An iron shuttle for deepwater silica in Late Archean and early Paleoproterozoic iron formations. Geological Society of America Bulletin, v. 121, pp. 222-235.

Fryer, B.J., Fyfe, W.S. and Kerrich, R., 1979, Archean volcanogenic oceans. Chemical Geology, v. 24, pp. 25-33.

German, C.R., Halliday, B.P. and Elderfield, R., 1991, Redox cycling of rare earth elements in the suboxic zone of the Black Sea. Geochimica et Cosmochimica Acta, v. 55, pp. 3535-3558

Hamade, T., Konhauser, K., Raiswell, R., Goldsmith, S. and Morris, R., 2003, Using Ge/Si ratio to decouple iron and silica fluxes in Precambrian banded iron formations. Geology, v. 31, pp. 35-38.

Harley, S.I. Kelly, N.M. and Möller, A., 2007, Zircon behavior and the thermal histories of mountain chains. Elements, v. 3, pp. 25-31.

Hoskin, P.W.O. and Schaltegger, U., 2003, The composition of zircon and igneous and metamorphic petrogenesis. In zircon (Hanchar, J.M. and Hoskin, P.W.O. Eds.). Reviews in Mineralogy and Geochemistry, 53, Mineralogical Society of America. Washington, D.C., pp. 27-62.

Ilouga, D. C. I., Suh, C.E., Tanwi, G.R. (2012, in Press). Textures and Rare Earth Elements Composition of Banded Iron Formations (BIF) at Njweng Prospect, Mbalam Iron Ore District, Southern Cameroon. International Journal of Geosciences

Kaufman, A.J., Johnston, D.T., Farquhar, J., Masterson, A.L., Lyons, T.W., Bates, S., Anbar, A.D., Anold, G.L., Garvin, J. and Buick, R., 2007, Late Archean biospheric oxygenation and atmospheric evolution. Science, v. 317, pp. 1900-1903.

Klein, C. and Beukes, N.J., 1989, Geochemistry and sedimentology of a facies transition from limestone to iron formation deposits in the early Proterozoic Transvaal Supergroup, South Africa. Economic Geology, v. 84 , pp. $1733-1774$.

Klein, C., 2005, Some Precambrian banded iron-formations (BIFs) from around the world: their age, geologic setting, mineralogy, metamorphism, geochemistry and origin. American Mineralogist, v. 90, pp. 1473-1499.

Konhauser, K. O., Hamade, T., Raiswell, R., Morris, R.C., Feris, F.G., Southam, G., and Canfield, D.E., 2002, Could bacteria have formed the Precambrian banded iron formations? Geology, v. 30, pp. 1079-1082.

Konhauser, K. O., Amskold, L., Lalonde, S.V., Posth, K.A. and Anbar, A., 2007b, Decoupling photochemical Fe (II) oxidation from shallow-water BIF deposition. Earth and Planetary Science Letters, v. 258, pp. 87-100.

Lerouge, C., Cocherie, A., Toteu, S.F., Penaye, J., Milési, J., Tchameni, R., Nsifa, E.N., Fanning, C.M. and Deloule, E., 2006, Shrimp U-Pb zircon age evidence for Paleoproterozoic sedimentation and $2.05 \mathrm{Ga}$ syntectonic plutonism in the Nyong Group, South Western Cameroon: consequences for the Eburnean Transamazonian belt of NE Brazil and Central Africa. Journal of African Earth Sciences, v. 44, pp. 413-427.

Ludwig, K.R., 2001, SQUID 1.03, A User's Manual; Berkeley Geochronology Center Special Publication, No. 2, 19 pp.

Ludwig, K.R., 2003, Isoplot 3.00: A Geochronological Toolkit for Microsoft Excel. Berkeley Geochronology Center Special Publication, No. 4, 70 pp.

Maliva, R.G., Knoll, A.H. and Simonson, B.M., 2005, Secular change in the Precambrian silica cycle: insights from chert petrology. Geological Society of America Bulletin, v. 117, pp. 835-845.

Marks, M., Halama, R., Wenzel, H. and Markl, G., 2004, Trace element variations in clinopyroxene and amphibole from alkaline to peralkaline syenites and granites: implications for mineral-melt trace-element partitioning. Chemical Geology, v. 211, pp. 185-215.

Mboudou, G.M.M., Suh, C.E., Mafany, G.T. (2012, in press). Geochemical characterization of Novokrivoyrog metavolcanics: Tetonic implications and Relationship with the early Proterozoic Banded Iron Formation (BIF) of Krivoy Rog in Ukraine. Open Journal of Geology.

Milesi, J.P., Toteu, S.F., Deschamps, Y., Feybesse, J.L., Lerouge, C., Cocherie, A., Penaye, J., Tchameni, R., Moloto-A-Kenguemba, G., Kampunzu, H.A.B., Nicol, N., Duguey, E., Leistel, J.M., Saint-Martin, M., Ralay, F., Heinry, C., Bouchot, V., Doumnang Mbaigane, J.C., Kanda Kula, V., Chene, F.; Monthel, M., Boutin, B. and Cailteux, J., 2006, An overview of the geology and major ore deposits of Central Africa: Explanatory note for the 1:4000, 000 map "Geology and major ore deposits of Central Africa”. Journal of African Earth Sciences, v. 44, pp. 571-595.

Möller, A.O., O’Brien, P.J., Kennedy, A., and Kröner, A., 2003, Linking growth episodes of zircons and metamorphic textures to zircon chemistry: an example from the ultrahigh temperature granulites of Rogaland (SW Norway). In Geochronology: Linking the isotope record with petrology and textures (Vance, D., Müller, W. and Villa, I.M. Eds.). Geological Society of London, Special Publication, no. 220, pp. $65-81$.

Morris, R.C., 1993, Genetic modeling for banded iron formations of the Hamersley Group, Pilbara Craton, Western Australia. Precambrian Research, v. 60, pp. 243-286.

Nance, W.B. and Taylor, S.R., 1976, Rare earth element patterns and crustal evolution-I. Australian post Archean sedimentary rocks. GCA 40, 1539.

Nforba, M. T., Suh, C.E. and Kabeyene, K.V.K., 2010, Mbalam iron ore project, northern edge of the Congo craton, southeast Cameroon. In: Goldfarb, R.J., Marsh, E.E. and Monecke, E. (editors): Proceedings of the Society of Economic Geologists "The challenge of finding new mineral resources: global metallogeny, innovative exploration and new discoveries", SEG Extended Abstracts, Colorado G-22.

Owona, S., 2008, Archean, Eburnean and Pan-African features and relationships in their junction zone in the south of Yaounde (Cameroon). $\mathrm{PhD}$ Thesis in the Geoscience Department of the University of Douala, Cameroon (Unpublished).

Pouclet, A., Tchameni, R., Mezger, K., Vidal, M., Nsifa, E.N., Shang, C.K. and Penaye, J., 2007, Archean crustal accretion at the northern border of the Congo craton (South Cameroon). The charnockite-TTG link. Bulletin of the Geological Society of France, v. 178, pp. 331-342.

Powell, C.McA., Oliver, N.H.S., Li, Z-X., Martin, D.McB. and Ronaszeki, J., 1999, Synorogenic hydrothermal origin for the giant Hamersley iron oxide ore bodies. Geology, v. 27, pp. 175-178.

Rubatto, D., 2002, Zircon trace element geochemistry: partitioning with garnet and the link between U-Pb ages and metamorphism. Chemical Geology, v. 184 , pp. $123-138$.

Schaltegger, U., Fanning, C.M., Günther, D., Maurin., J.C., Schulmann, K. and Gebauer, D., 1999, Growth annealing and recrystallization of zircon and the preservation of monazite in high grade metamorphism: conventional and in situ $\mathrm{U}-\mathrm{Pb}$ isotope, cathodluminescence and microchemical evidence. Contributions to Mineralogy and Petrology, v. 134, pp. 186-201.

Shang, C.K., 2001, Geochemistry and geochronology of Archean rocks from the Sangmelima Region, Ntem Complex, NW Congo craton, South Cameroon. Ph.D Thesis, University of Tübingen, Germany, pp.313.

Shang, C.K., Satir, M., Siebel, W., Nsifa, E.N., Taubald, H., Liégeois, J.P. and Tchoua, F.M., 2004a, TTG magmatism in the Congo craton: case study of the Sangmalima region, Ntem Complex, southern Cameroon. Journal of African Earth Sciences, v. 40, pp. 61-79.

Shang, C.K., Satir, M., Nsifa, E.N., Liegeois, J.P., Siebel, W. and Taubald, H., 2007, Archean high K-granitoids produced by remelting of early Tonalite-Trondhjemite-Granodiorite (TTG) in the Sangmelima region of the Ntem Complex of the Congo craton, southern Cameroon. International Journal of Earth Sciences, v. 96, pp. 817-842.

Shang, C.K., Liégeois, J.P., Satir, M., Frisch, W. and Nsifa, E.N., 2010, Late Archaean high-K granite geochronology of the northern metacratonic 
margin of the Archaean Congo craton, Southern Cameroon: Evidence for Pb-loss due to non-metamorphic causes. Gondwana Research, v. 18, pp. 337-355.

Sholkovitz, E.R., Landing, W.M. and Lewis, B.L., 1994, Ocean particle chemistry: the fractionation of rare earth elements between suspended particles and seawater. Geochimica et Cosmochimica Acta, v. 58, pp. 1567-1579.

Siever, R., 1992, The silica cycle in the Precambrian. Geochim. Cosmoschim. Acta, v. 56, pp. 3265-3272.

Steiger, R.H. and Jäger, E., 1977, Subcommision on geochronology: convention on the use of decay constants in geo- and cosmochronology. Earth Planetary Science Letters, v. 36, pp. 359-362.

Steinhoefel, G., von Blanckenburg, F., Horn, I., Konhauser, K.O., Beukes, N.J. and Gutzmer, J., 2010, Deciphering formation processes of banded iron formations from the Transvaal and the Hamersley successions by combined $\mathrm{Si}$ and $\mathrm{Fe}$ isotope analysis using UV femtosecond laser ablation. Geochim. Cosmochim. Acta, v. 74, pp. 2677-2696.

Suh, C.E., Cabral, A.R., Shemang, E.M., Mbinkar, L. and Mboudou, G.G.M., 2008, Two contrasting iron deposits in the Precambrian mineral belt of Cameroon, West Africa. Exploration and Mining Geology, v. 17, pp. 197-207.

Suh, C.E., Cabral, A.R. and Ndime, E., 2009, Geology and ore fabrics of the Nkout high-grade hematite deposit, southern Cameroon. In: P.J. Williams et al. (editors), Smart Science for Exploration and Mining, SGA Publication series pp. 558-560.

Sumner, D.Y. and Bowring, S.A., 1996, U-Pb geochronologic constraints on deposition of the Campbellrand Subgroup, Transvaal Supergroup, South Africa. Precambrian Research, v. 79, pp. 25-35.

Sun, S.S. and McDonough, 1989, Chemical and isotopic systematic of oceanic basalts: implications for mantle composition and processes. Geological Society Special Publication, No. 42, pp. 313-345.
Svenjensky, D.A., 1981, The origin of Mississippi Valley-type deposit in the Viburnum Trend, southeast Missouri. Economic Geology, v. 76, pp. 1848 1872

Takam, T., Arima, M., Kokonyangi, J., Dunkley, D.J., and Nsifa, E.N., 2009, Paleoarchean charnockite in the Ntem Comples, Congo Craton, Cameroon: insights from SHRIMP zircon U-Pb ages. Journal of Mineralogical and Petrological Sciences, v. 104, pp. 1-11.

Tchameni, R., Mezger, K., Nsifa, N.E. and Pouclet, A., 2000, Neoarchean evolution of the Congo craton: evidence from K-rich granitoids of the Ntem Complex, southern Cameroon. Journal of African Earth Sciences, v. 30 , pp. $133-147$.

Tchameni, R., Mezger, K., Nsifa, N.E. and Pouclet, A., 2001, Crustal origin of early Proterozoic syenites in the Congo craton (Ntem Complex), southern Cameroon. Lithos, v. 57, pp. 23-42.

Toteu, S.F., Van Schmus, W.R. Penaye, J. and Nyobe, J.B., 1994, U-Pb and Sm-Nd evidence of Eburnean and Pan-African high grade metamorphism in cratonic rocks of southern Cameroon. Precambrian Research, v. 67, pp. 321-347.

Trendall, A.F., Basei, M.A.S., de Laeter, J.R. and Nelson, D.R., 1998, SHRIMP zircon U-Pb constraints on the age of the Carajás Formation, Grão ParáGroup Amazon Craton. Journal of South American Earth Sciences, v. 11, pp. 265-277.

Trendall, A.F., Compston, W., Nelson, D.R., De Laeter, J.R. and Bennett, V.C., 2004, SHRIMP zircon ages constraining the depositional chronology of the Hamersley Group, Western Australia. Australian Journal of Earth Sciences, v. 51, pp. 621-644.

Williams, I.S., 1998, U-Th-Pb geochronology by ion microprobe. In: Reviews of microanalytical techniques to understanding mineralising processes, McKibben, M.A., Shanks, III, W.C. and Ridley, W.I. (eds), Reviews in Economic Geology, v. 7, pp. 1-35.

\section{Appendices}

\section{Appendix 1: Ages of iron ore-related BIFs in some major cratons around the world}

\begin{tabular}{|l|l|l|l|l|}
\hline \multicolumn{1}{|c|}{ Craton } & \multicolumn{1}{|c|}{ Location } & \multicolumn{1}{c|}{ Method } & \multicolumn{1}{c|}{ Age } & References \\
\hline Kaapvaal & $\begin{array}{l}\text { Kuruman and Penge Iron } \\
\text { Formations }\end{array}$ & $\begin{array}{l}\text { TIMS U-Pb } \\
\text { on zircons }\end{array}$ & $\begin{array}{l}\text { Sumner and Bowring, } \\
1996\end{array}$ \\
\hline Kaapvaal & Kuruman Iron Formation & $\begin{array}{l}\text { SHRIMP U-Pb } \\
\text { on zircons }\end{array}$ & $2446 \mathrm{Ma}$ & Pickard, 2003 \\
\hline Pilbara & $\begin{array}{l}\text { Weeli Wolli Iron Formation } \\
\text { of the Hamersley Group, Australia }\end{array}$ & $\begin{array}{l}\text { SHRIMP U-Pb } \\
\text { on zircons }\end{array}$ & $2449 \pm 3 \mathrm{Ma}$ & Barley et al., 1997 \\
\hline Pilbara & $\begin{array}{l}\text { Brockman Iron Formation } \\
\text { of the Hamersley Group, Australia }\end{array}$ & $\begin{array}{l}\text { SHRIMP U-Pb } \\
\text { on zircons }\end{array}$ & $2495 \mathrm{Ma}$ & Trendall et al., 2004 \\
\hline Pilbara & $\begin{array}{l}\text { Brockman Iron Formation } \\
\text { of the Hamersley Group, Australia }\end{array}$ & $\begin{array}{l}\text { Re-Os age on } \\
\text { pyrites }\end{array}$ & $2501 \pm 8 \mathrm{Ma}$ & Anbar et al., 2007 \\
\hline São Francisco & $\begin{array}{l}\text { BIFs of the Cauê Formation, } \\
\text { Itabira Group, Minas Supergroup, } \\
\text { Quadrilátero Ferrifero, Brazil }\end{array}$ & $\begin{array}{l}\text { Pb/Pb isochron on } \\
\text { carbonate rocks using } \\
\text { dual-leach procedure }\end{array}$ & $2520 \mathrm{Ma}$ & Babinski et al., 1995 \\
\hline São Francisco & $\begin{array}{l}\text { Iron Formations of the Carajàs } \\
\text { Formation, Grão ParáGroup, } \\
\text { Minas Supergroup, Quadrilátero } \\
\text { Ferrifero, Brazil }\end{array}$ & $\begin{array}{l}\text { SHRIMP U-Pb on } \\
\text { zircons obtained from } \\
\text { metarhyolites }\end{array}$ & $2750 \mathrm{Ma}$ & Trendall et al., 1998 \\
\hline Superior & $\begin{array}{l}\text { Iron Formations of the } \\
\text { Manitouwadge Greenstone belt }\end{array}$ & $\begin{array}{l}\text { Single-zircon } \\
\text { Pb-evaporation }\end{array}$ & $\begin{array}{l}720 \pm 2 \mathrm{Ma} \text { and } \\
22675 \pm 1 \mathrm{Ma}\end{array}$ & Pan and Fleet, 1995 \\
\hline
\end{tabular}




\section{Appendix 2: Global map showing cratons distribution and age variation of BIFs in some major iron ore districts of the world. Note the gap in the Congo craton (modified after Beukes and Gutzmer, 2008)}

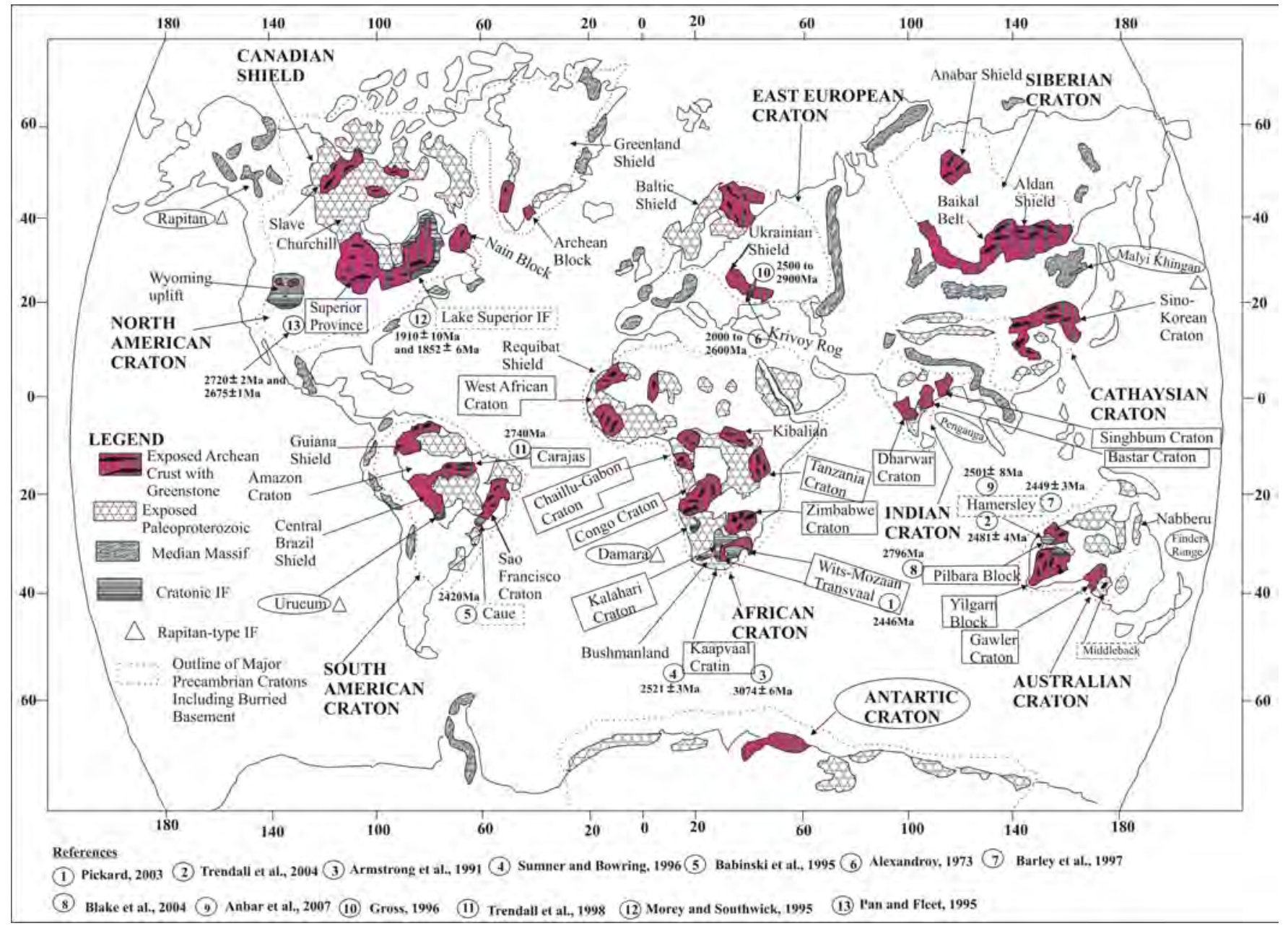

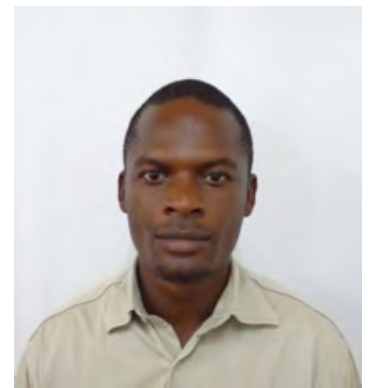

Nelson Chombong is a PhD student at the University of Buea, Cameroon with a keen interest on economic geology of iron and gold deposits. He is also a senior exploration geologist with Cameroon Mining Action Limited. He holds a M.Sc. degree in Applied Geology from the University of Buea and his thesis that focused on the geochemistry of iron formations in Paleoproterozoic rocks in southern Cameroon was supported by a Society of Economic Geology (SEG) student grant.

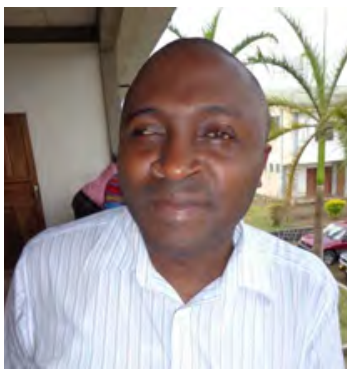

Cheo Emmanuel Suh is Professor of Economic Geology and Microtectonics at the University of Buea and a Fellow of the Humboldt Foundation. He is currently Head of Department and has developed various research projects in the area of economic geology, structural geology and volcanology. His current projects target the economic geology of the Precambrian mineral belt of Cameroon as well as the petrochemistry of volcanic rocks at the active Mount Cameroon volcano. 